\title{
ISLAND OF THE WORLD MOVING THE WORLD STRATEGIC CENTER FROM HEARTLAND TO THE INDIAN OCEAN
}

\author{
Luca DIACONESCU * \\ University of Oradea, Doctoral School of geography, 1st, Universității St., 410087, Oradea, Romania, \\ e-mail: diaconesculuca@yahoo.ro
}

Citation: Diaconescu, L. (2020). Island of the World Moving the World Strategic Center from Heartland to the Indian Ocean. Revista Română de Geografie Politică, 22(1), 1-8. https://doi.org/10.30892/rrgp.221101-333

\begin{abstract}
The theory of Heartland and Rimland where it is considered that whoever dominates the center of Eurasia will dominate the World Island and through this the whole world, tends to lose its relevance with the overpopulation of Sub-Saharan Africa and southern Asian half, all concentrated mainly around the new demographic center, economic, commercial and global decision-making for the $21^{\text {st }}$ century, the Indian Ocean.
\end{abstract}

Key words: population, Rimland, Eurasia, Africa, year 2100

\section{INTRODUCTION}

Rimland is the strip of land and islands between Heartland and the Planetary Ocean, stretching to the west, south and east of Eurasia, circling the large landmass between central-eastern Europe and the Far East, concepts supported by American geopoliticians of British origin Mackinder (Heartland theory) and Dutch origin Spykman (Rimland theory). According to them, Rimland has the world's largest demographic centers and is easily accessible from Heartland, so who will lead the desolate landmass called Heartland, will rule Eurasia and who will rule Eurasia will rule the Island of the World and thus the entire planet (Kaplan, 2015; Dobrescu, 2008; Meinig, 1956).

Heartlandul to Mackinder was designed in 1904 and Rimlandul to Spykman in the year 1942, at a time when Eurasia had about $80 \%$ of the world's population. In the meantime, the World Island, which includes Asia and Europe and the continent of Africa, holds and will continue to hold values around $85 \%$ of the world's population, only that Europe's demographic center will be replaced by Africa (O'Brien, 2010; Gray, 1977). It held only a quarter of Europe's population in 1900 , reaching similar values in 1995, having a double population compared to 
the European population by 2023 and even 7 times more by 2100 , when Africa will hold over $40 \%$ of the world's population resembles Asia at that time.

Thus it can be considered that Rimlandului theory it becomes less and less functional with the changing demographic poles of the world and Heartlandul which was surrounded by $75 \%$ of the world's population in 1900 it will still hold around $50 \%$ in 2100 , following as the waters of the Indian Ocean south of Heartland to have on the land around them, over $60 \%$ of the world's population. The main economic poles of Rimland in the twentieth century were in its temperate areas in Europe and East Asia (Japan and China) as well as the central-south Heartland represented by Russia and the satellite states. In the $21^{\text {st }}$ century, it seems that both the demographic power followed by the economic and natural power and the commercial power descend towards the warmer tropical areas of the south, areas that were subject to the Nordic powers, with serious economic deficiencies, with areas of hunger, incurable diseases and impractical jungle like the picture of sub-Saharan Africa and southern half of Asia at the beginning of the $20^{\text {th }}$ century.

\section{THEORY OF HEARTLAND AND THE RIMLAND, YEAR 1900}

In 1900, the population of the World Island had almost $90 \%$ of the population of the planet, representing a large land mass composed of: Europe, Asia and Africa, which also had similar proportions in the world economy, concentrated in its temperate areas located in Europe, Central Asia and East Asia, encompassing major demographic, commercial and colonial empires such as: England, France, Russia, Austro-Hungary, Japan, China, Spain, Portugal, Germany, the Ottoman Empire or Italy (Ilieș, 2006; Mâșu, 2014; Carvalho and Dughin, 2016). In the tropical area south of the aforementioned region, there was Africa and the southern half of Asia, represented by colonies subject to the temperate north, inhospitable, unfit for economic development and less populated (Herman and Grama, 2018; Millemann, 2008; Harvey, 2004). Africa had just over 100 million inhabitants on a territory three times larger than Europe, the latter having 400 million people and a demographic density 12 times higher. Also, East Asia, made up of China and Japan, all in a temperate zone, had more population than South Asia (India, Pakistan and so on), South East Asia (Indonesia, Philippines, Vietnam, Thailand and so on) and Southwest Asia (Iran, Iraq, Saudi Arabia and so on) together. It is understandable why the theory of the Heartland, which represented the middle of the temperate zone of the north of the World Island, a territory dominated by Russia in the north, England in the south (through its colonies in India, Iran and Tibet), China in the east and the Ottoman Empire in the west, emerged period when the warm waters of the Indian Ocean surrounded shores of low geopolitical value.

But the reality at the beginning of the $20^{\text {th }}$ century seems to be very different from the situation in 2020, when Africa from just 25\% of Europe's population reaches it and even doubles it. In the same period, the East Asian states, which exceeded the total population of the South Asian half in the year 1900, are overtaken by the population of the south and are even exceeded by 1.1 billion people, both trends continuing until after 2100. Thus, the main demographic concentration that existed in the northern half of Eurasia at the level of 1900, tends to focus today predominantly around the waters of the Indian Ocean, while there is an increasingly visible trade blockade in Heartland, which forces states interested in trade in the area to move its commercial axes south through the oceanic waters. 
Table 1. Comparison of the evolution of the population of Rimland, Heartland and Africa, between 1900 and the estimate for 2100, in millions of inhabitants Source: Times Books, 2000; Reader,s Digest, 2008; Worldometers, 2019;

Gaceu, 2007; Peptenatu et al, 2005; Muntele, 2010.

\begin{tabular}{|c|c|c|c|c|c|c|}
\hline$\dot{0}$ & 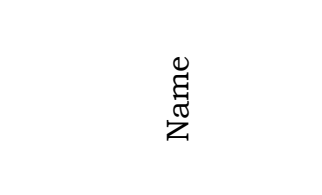 & 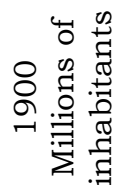 & $\begin{array}{l}0 \\
\text { ำ } \\
\text { - }\end{array}$ & ণิ & 유 & $\begin{array}{l}\stackrel{8}{\circ} \\
\stackrel{1}{v}\end{array}$ \\
\hline 1 & WORLD & 1.600 & 2.520 & 7.800 & 9.800 & $10.600-13.000$ \\
\hline 2 & Island of the World & 1.450 & 2.200 & 6.730 & 8.550 & $9.700-12.000$ \\
\hline 3 & $\begin{array}{l}\text { Heartland and } \\
\text { Rimland }\end{array}$ & 1.300 & 2.000 & 5.380 & 6.100 & $5.400-7.000$ \\
\hline 4 & Heartland & 95 & 150 & 340 & 380 & $300-400$ \\
\hline 5 & $\begin{array}{l}\text { Rimlandul from } \\
\text { eastern Chinese- } \\
\text { Japanese }\end{array}$ & 470 & 700 & 1.680 & 1.700 & $1.100-1.500$ \\
\hline 6 & $\begin{array}{l}\text { Rimlandul } \\
\text { southeastern } \\
\text { Indochinese } \\
\end{array}$ & 74 & 170 & 670 & 800 & $700-1000$ \\
\hline 7 & $\begin{array}{l}\text { Rimlandul of } \\
\text { south Indian }\end{array}$ & 300 & 460 & 1.820 & 2.250 & $2.300-2.800$ \\
\hline 8 & $\begin{array}{l}\text { Rimlandul from } \\
\text { southwestern } \\
\text { Arabic-Persian }\end{array}$ & 50 & 90 & 320 & 410 & $500-700$ \\
\hline 9 & $\begin{array}{l}\text { Rimlandul western } \\
\text { European }\end{array}$ & 300 & 440 & 550 & 560 & $480-550$ \\
\hline 10 & $\begin{array}{l}\text { New west Rimland } \\
\text { (central-east Africa) }\end{array}$ & 50 & 100 & 650 & 1.175 & $2.100-2400$ \\
\hline 11 & $\begin{array}{l}\text { Atlantic Africa } \\
\text { (central-western) }\end{array}$ & 60 & 110 & 690 & 1.315 & $2.250-2.650$ \\
\hline
\end{tabular}

\section{GEOGRAPHICAL AND DEMOGRAPHIC PRESENT, YEAR 2020}

A frenchman cannot trade with Japan through Russia or China or with India through Pakistan or with Iran through Saudi Arabia, such examples in everything exist throughout the Heartland (Roy, 2001; Ionescu, 2005). In contrast, the waters of the seas and oceans are much safer. With all the conflict between Saudi Arabia and the Yemeni state dominating the Bad-el-Mandeb Strait, connecting the Indian Ocean with the Red Sea, Saudi Arabia can cross these waters between its cities on the Red Sea and those on the Persian Gulf (Marshall, 2019; Gâștescu and Cioacă, 2013; Mazilu, 2008). Also, Pakistan crosses the waters of the Gulf of Mannar from southern India to reach Bangladesh, India crosses the waters of Pakistan to Iran and China crosses the waters of Vietnam or Japan, even though between these states there are tensions and even blocked land borders. Compared to the maritime borders, the terrestrial borders are complicated by causing the Heartland to be functionally blocked, hostile to the climate and geologically, and the states that occupy or adjoin it are in a crisis of space, ideological and religious, leading to inhospitable borders commercial (Marin and Marin, 2008; Huntington, 2018). Therefore, the safest trade routes and with high fluctuation between the 5 mega demographic centers surrounding Heartland, are the warm waters of the Indian Ocean and the straits that link it to the 
European Mediterranean and South-East Asia, bringing as a bonus, direct access to the new mega-center in full process of demographic explosion located in the central-southern part of Africa. China has at least 7 maritime routes to the Indian Ocean crossing through Indonesia and Malaysia, a semi-maritime route through the Kra isthmus in southern Thailand and at least two favorable land routes through Myanmar and Pakistan. The same situation is also from the European Union to the Indian Ocean, there are two states with exit to both the Mediterranean and the Red Sea (Egypt and Israel), as well as 5 other routes crossing only two states: Libya-Sudan, Syria-Jordan, Syria -Irak, Turkey-Iraq, Turkey-Iran. Thus, China can bypass the tense border it has with Russia or religious disputes with Central Asia, reaching Europe through the waters of the Indian Ocean (Navarro, 2011; Burrows, 2016). And India, which is mainly surrounded by inhospitable states, can bypass its border with China for trade with Japan or South Korea, as well as the tense border with Pakistan for its trade to the northwest with Russia and the European Union.

All these blockages that have increased with the economic development and the Asian demographic explosion produced during the $20^{\text {th }}$ century, have shown that the possibility of building high-flow trade axes that cross the Heartland is almost impossible, unstable and absorbs large financial efforts. The entire land mass of Eurasia it is difficult to cross with all the efforts made by the states that compose it in facilitating the practice of commercial transport. These are type blockages:

- geologically made up of: The Himalayas, Tibet Plateau, Tian Shan and Altai Mountains, limiting access between China and India, Pakistan, Afghanistan or Russia;

- climate in northern Eurasia (Siberia) with the predominance of polar climate;

- such as deserts: Gobi (China), Turan (Central Asia), Arab (Saudi Arabia), Lut (Iran) or Thar (Pakistan and India);

- religious such as the line of Islamist interference and: Orthodox Christian between Russian and Islamic civilization (Central Asia, Caucasian states) or Byzantine-Ottoman (between Greece and Turkey); Christian Catholic (Philippines); Hindu (Pakistan-Bangladesh and India); Buddhist (Thailand); Judaism (Israel) and Confucianism (China), as well as the Islamist conflict between Shiites (Iran, Azerbaijan, Iraq, Yemen) and Sunni;

- economic, ideological and historical: Russia - Ukraine, European Union, Japan, China; China - Japan, Taiwan, Vietnam, India, Thailand, Philippines; North Korea - South Korea, Japan; Thailand - Vietnam; Saudi Arabia - United Arab Emirates;

These tensions or natural limits make it difficult to access Heartland and Rimland, but also within them.

A second and increasingly significant and not immediately relevant change when Heartland theory was issued is the descent to the global demographic center from the temperate areas of the north at the equator and from the domination of the population in number of inhabitants around the Pacific and Atlantic Oceans to the population around the Indian Ocean (Diaconescu, 2017; 2018). Thus, the population of Eurasia with access to the Indian Ocean is gaining ground in front of the number of inhabitants from the states with access to the Pacific and Atlantic Oceans, and the African coastline, although not considered as a major demographic region, tends to replace the demographic dominance held by Asia until at the end of the $21^{\text {st }}$ century (Diaconescu et al., 2019). Similar to the situation in Romania, the entire population of the European Union, Russia, 
Japan or China is experiencing a worrying downward trend in the number of inhabitants (Stassac, 2009). The rimland as it was designed in 1900 had $75 \%$ of the world's population, currently falling to only $65 \%$ and probably $50 \%$ by 2100 . Also within the Rimland, the Pacific Ocean states such as: China, Japan, Korea, Vietnam or the Philippines in the Asia-Pacific and the Atlantic Ocean States that are represented by Europe and a part of the Near East, ie the two neighboring extremes of Heartland they owned $67 \%$ of the total population of Rimland in 1900 (50\% of the population of the Earth), decreasing to only $54 \%$ at present (35\% of the population of the Earth) and probably between $37 \%$ and $46 \%$ by 2100 (18-23\% of the population of the Earth), demonstrating a decrease of the demographic poles from the temperate area towards the hot surfaces that limit the North Indian Ocean.

Table 2. The evolution of the population on different geographical regions of the World Island, in millions of inhabitants and percentages of the world population, between 1900 and an estimate for 2100

Source: Diaconescu, 2016; Worldometers, 2019

\begin{tabular}{|c|l|c|c|c|}
\hline No. & \multicolumn{1}{|c|}{ Name } & 1900 & 2020 & 2100 \\
\hline 1 & World & $100 \%$ & $100 \%$ & $100 \%$ \\
& (population millions of inhabitants) & $(1.600)$ & $(7.800)$ & $(10.600-13.000)$ \\
\hline 2 & The population of Rimland & $75 \%$ & $64 \%$ & $48-50 \%$ \\
& (from World total) & $(1.200)$ & $(5.000)$ & $(5.100-6.600)$ \\
\hline 3 & The population of Rimland states with & $50 \%$ & $35 \%$ & $18-23 \%$ \\
& an exit to the & $67 \%$ & $54 \%$ & $37-46 \%$ \\
& Pacific and Atlantic oceans & $(800)$ & $(2.700)$ & $(1.900-3.050)$ \\
& (from World and Rimland total) & $25 \%$ & $29 \%$ & $27-30 \%$ \\
\hline 4 & The population of Rimland states with & $48 \%$ & $46 \%$ & $54-63 \%$ \\
& an exit to the Indian ocean & $(400)$ & $(2.300)$ & $(3.200-3.550)$ \\
\hline 5 & (from World and Rimland total) & $7 \%$ & $17 \%$ & $41-42 \%$ \\
& The population of Africa & $(110)$ & $(1.340)$ & $(4.350-5.500)$ \\
\hline
\end{tabular}

Currently, there is an obvious economic miracle known to the states close to the Indian Ocean in the southern half of Asia and the eastern half of Africa, with annual growth rates in general of over $4-5 \%$, falling slightly in the more distant states such as Central Asia, Asia South-East, Eastern Europe or central-west Africa where rates average between $2-5 \%$ (the only exception is in East Asia where China has $7 \%$ annual growth rates similar to those around the Ocean Indian), falling even further in the states further afield, with values of less than $2 \%$ annual economic growth as is the case of the states of Western Europe, America or northeastern Asia (Japan). Asia as a whole is experiencing annual economic growth of $5 \%$, Africa of $3 \%$ and America and Europe of $2 \%$ and $1.5 \%$ respectively.

\section{THE INDIAN OCEAN COMES TO THE WORLD} GEOSTRATEGIC CENTER, YEAR 2100

The demographic decline recorded in Rimland by which it declines as the dominant demographic belt of the world decreases in its entirety, but separated separately, only its western and eastern parts are declining, the southern part having access to the Indian Ocean is still experiencing a demographic explosion. Further south of Rimland, also on the shores of the Indian Ocean rises vertiginously another demographic pole that comes to complement the South 
Asian, being an extension of it. Thus the entire demographic power followed in the near future by an economic and commercial power, descends from the center of Eurasia towards its south, reaching the center of the World Island, being located approximately between South-South-West Asia and the north of the Indian Ocean, possibly even an extension east to the Nile Delta and the Heights of the Ethiopian Plateau and west to Indochina. Thus, it can be considered that whoever dominates the states around the Bay of Bengal, the Persian Gulf and the northern waters of the Indian Ocean, will dominate the entire Island of the World and hence the entire World. Without the geological or climatic impediments that are found in Heartland but also without possible trade blockages, as it is between the different religious, ideological or commercial belonging that impede access between the deserted Heartland and the overcrowded Rimland, the North Indian Ocean seems a safer way of access for all the large demographic centers in the west, south and east of Heartland but also towards central-east Africa, which tends to represent the new global demographic pole, hardly accessible from the high peaks existing in Heartland.

In the 1900s when the term Heartland appeared, the population around it (Rimland) owned $75 \%$ of the world's population (its southern half having access to the Indian Ocean with only $25 \%$ of the world's total population) while Africa held only $7 \%$. States around the Indian Ocean could not be of particular interest to geopolitics, accounting for only $32 \%$ of the world's population, while Europe and East Asia (China, Japan, Korea) held 50\% of the world's population, also representing the main economic and political poles, the headquarters of the great empires that dominated the world at that time. In contrast, by 2100 the two extremes will only hold between 18 and $23 \%$ of the world population, while the southern half of Asia will reach $27-30 \%$ of the world population, and Africa at $41-42 \%$ representing in the world total $70 \%$ of the population from only $32 \%$ as they were in 1900 .

It is foreseeable that by 2100 , states with claims to world economic dominance will not be able to reach superpowers without territorial or at least commercial and / or military domination in the Indian Ocean. In addition to the future Indian superpower that will dominate the waters of the Indian Ocean and will most likely become the world's first power, co-exist with it and other world superpowers such as: China through Burma (a possible union could be formed, holding note that the two states have Buddhist religion and languages that belong to the large Sino-Tibetan family); The European Union through Israel, which it is most likely to co-opt; the western half of Africa will have access through the eastern half states most likely to form the African Union or various other smaller unions; Russia will have access through Iran and the US or Japan most likely through a Southeast Asian state (possibly the ASEAN Union) or directly through India.

It is uncertain what the global political scene will look like at the end of the $21^{\text {st }}$ century, but we know for sure that the heavily populated regions tend to attract wealth and export culture and emigrants, dominating less populated areas over time, and the most populated regions in the world they have two clear directions: from the temperate area to the warmer areas of the equator and from the shores of the Pacific and Atlantic oceans, to the shores of the Indian Ocean as a whole regions with a warm climate. Also, we know for sure after the developments of the last 12 decades, that regardless of the obstacles that have occurred over time such as the great world wars or the formation of the 
communist bloc, trade has grown steadily and the main form of trade on a planetary scale it is naval transport (which currently accounts for $90 \%$ of all world trade) and will continue to dominate, to the detriment of land transport too restrictive.

\section{CONCLUSIONS}

The evolution of the world economy is constantly changing, migrating from one territory to another over several centuries, accompanying with a slight delay, the movement of the large demographic areas. If Europe dominated the world economy in 1900, in 1950 it seems that North America with the dominant US power plays this role, and in 2000 it will easily surrender to East Asia (Japan, China). By 2050 probably the southern half of Asia (India, Indonesia, Vietnam, the Philippines, Pakistan, Iran, Turkey, Saudi Arabia, etc.) will be the world economic center followed by 2100 sub-Saharan Africa (Tanzania, Ethiopia, Nigeria, Congo DR., South Africa, Kenya, Angola, Mozambiq etc). Thus, every man who lives more than 7-8 decades, finds that as he gets older, the geography: economic, demographic, political or commercial that he has been taught in graduate schools, tends to become erroneous in the new planetary reality.

One of these major changes occurs during this time, and the demographic, economic, political and commercial primacy that existed in the 1900s, 1950s and 2000s when the world power was in turn held by Europe, the United StatesCanada and Japan-China, all located in the northern hemisphere, in its temperate area known as geopolitics as the triad of world power, it is increasingly moving to the new global demographic centers located in the tropical climate area of southern half of Asia, followed by sub-Saharan Africa.

If in 1900, East Asia (China, Japan) had 470 million people, followed by Central-Western Europe and South Asia (India) with 300 million every, by 2100 East and West Rimland together reach the one more likely 1.8 billion people (East Asia increases from 0.47 to 1.3 billion people and central-western Europe from 0.3 to 0.5 billion) while South Rimland (India, Pakistan, Bangladesh) grow from 0.3 billion inhabitants in 1900 to 2.5 billion, well above China, Japan and Europe at one place. Also, the sides of the Rimland descend in demographic power from the temperate zone to the tropical area, so in the west, in year 1900 Central-Western Europe dominates with 300 million inhabitants being 6 times more population than in the South-West Rimland (Turkey, Iran, Iraq, Syria, Saudi Arabia, Yemen, etc., which had only 50 million people, and by 2100 both would have 500 million inhabitants, and on the eastern side, East Rimland (China, Japan) more than 6 times more population with the 470 million people, than South-East Rimland (Indonesia, Philippines, Vietnam, Thailand, Myanmar, Malaysia, etc.) which had only 74 million people in 1900, in the year 2100 each has 1.0 billion inhabitants. For this picture to be complete, in addition to the demographic advance and, most likely, followed by a devastating and economical advance of the southern Rimland with access to the Indian Ocean and located in the tropical area, to the detriment of the northern Rimland located in the temperate zone, it is completed by the new demographic bomb of the $21^{\text {st }}$ century, the continent of Africa growing from only 110-120 million inhabitants in 1900 , to probably over 5.0 billion inhabitants by 2100 , with an increase of 50 times, gravitating as power economic in tandem with the southern half of Asia, around the waters of the Indian Ocean. 


\section{REFERENCES}

Burrows, M. (2016). Viitorul declasificat. Megatendințele care ne-ar putea distruge lumea (The declassified future. Megatendencies that could destroy our world), Litera Publishing House, București (in Romanian).

Carvalho, O., Dughin, A. (2016). Statele Unite şi Noua Ordine Mondialä (United States and the New World Order), Humanitas Publishing House, București (in Romanian).

Diaconescu, L. (2017). Global Competition Between North and South. Revista Română de Geografie Politică, 19(2), 103-115.

Diaconescu, L. (2018). Geopolitics of the Oceans: The Demographic Influence in the Separation of Powers. Revista Română de Geografie Politică, 20(2), 75-85.

Diaconescu, L. (2016). Cities versus states: demographic evolution. Geographica Timisiensis, 25(1).

Diaconescu, L., Nichituț, N., Lung, M.S. (2019). Colossi-Crumbs in the year 1900 - Colossi-Colossi in the year 2100. Transfer of demographic-economic predominance from Eurasia to Afroamerica. Revista Română de Geografie Politică, 21(2), 50-59.

Dobrescu, P. (2008). Geopolitica, Comunicare.ro Publishing House, București (in Romanian).

Meinig, D. W. (1956). Heartland and rimland in Eurasian history. Western Political Quarterly, 9(3), 553-569.

Gaceu, O. (2007). Asia, Oceania și Australia, Editura Universității din Oradea, Oradea (in Romanian).

Gâștescu, P., Cioacă, A. (2013). Insulele Terrei (Earth Islands), Editura CD Press, București (in Romanian).

Gray, C. S. (1977). Geopolitics of the nuclear era: heartland, rimlands, and the technological revolution. Hudson Inst., NY.

Harvey, D. (2004). Noul imperialism (The new imperialism), Bic All Publishing House, București (in Romanian).

Herman, G.V., Grama, V. (2018). Geographical aspects of space-time evolution of independent states, Revista Română de Geografie Politică, 20(2), 49-56.

Huntington, S.P. (2018). Ciocnirea civilizațiilor și refacerea ordinii mondiale (The clash of civilizations and the restoration of world order), Litera Publishing House, București (in Romanian).

Ilieș, A. (2006). Elemente de geografie politică: Spațiul european (Elements of Politica Geography) Editura Universitătii din Oradea (in Romanian).

Ionescu, M. E. (2005). Sfidarea Westphaliei. Politeia-SNSPA.

Kaplan, R.D. (2015). Răzbunarea geografiei. Ce ne spune harta despre conflictele viitoare și lupta impotriva destinului (Revenge of geography. What the map tells us about future conflicts and the fight against destiny), Litera Publishing House, București (in Romanian).

Marin, M., Marin, I. (2008). Medii și regiuni geografice (Geographic environments and regions), Universitară Publishing House, București (in Romanian).

Marshall, T. (2019). Prizonierii geografiei. Zece hărți care ưți spun tot ce trebuie să ști despre politica globală (The prisoners of geography. Ten maps that tell you everything you need to know about global politics), Litera Publishing House, București (in Romanian).

Mazilu, M.E. (2008). To be or not to be afraid of globalizationin Journal?, Analele Universității din Craiova, Seria Geografie, 11, 87-91 (in Romanian).

Mâșu, Ș. (2014). Puterea economică în istoria lumii. De la Marele Rift la Marele Război din 1914 (Economic power in the history of the world. From the Great Rift to the Great War of 1914), Rao Publishing House, București (in Romanian).

Millemann, T.P. (2008). Fața ascunsă a lumii occidentale (The hidden face of the Western world), Pro Editură și Topografie Publishing House, București (in Romanian).

Muntele, I. (2010). Riscuri geo-demografice în Europa - Relații și perspective (Geo-demographic risks in Europe - Reality and perspectives), Studii și Cercetări în Geoștiințe, 1, 65-82 (in Romanian).

Navarro, P. (2011). China - Războaiele care vor veni: unde vor fi duse și cum pot fi câsstigate (ChinaThe wars to come: where they will beand how they can be won), Niculescu Publishing House, București (in Romanian).

O'Brien, Michel, D. (2010). The Island of the World, Ignatius Press Publishing House, USA.

Peptenatu, D., Drăghici, C., Cepoiu, L.A. (2005). Geografie economică mondială, Ediția a II-a (World Economic Geography, $2^{\text {nd }}$ Edition II), Universitară Publishing House, București (in Romanian).

Roy, O. (2001). Noua Asie Centrală sau Fabricarea națiunilor (New Central Asia or Manufacture of Nations), Dacia Publishing House, Cluj-Napoca (in Romanian).

Staşac, M. (2009). Aspects of the Phenomenon of Demographic Population Aging in Romania and the Republic of Moldava in the Context of the European Union Perspective. Revista Română de Geografie Politică, 11(1), 58-64.

*** (2008). Marele Atlas Universal (The Great Universal Atlas), Reader,s Digest Publishing House, București.

*** (2000). The Times Concise Atlas of the World, Times Books Publishing House, eighth edition, Spain.

Worldometers, real time world statistics: www.worldometers.info, last accessed, November, 2019.

Submitted:

December 10, 2019
Revised:

January 20, 2020
Accepted and published online:

February 06, 2020 